\title{
HRAD PEŤUŠA - ŠL'ACHTICKÉ SÍDLO ALEBO MÝTNA STANICA? KONFRONTÁCIA ARCHEOLOGICKÝCH A HISTORICKÝCH PRAMEŇOV
}

\author{
NOÉMI BELJAK PAŽINOVÁ - RADOSLAV RAGAČ
}

\begin{abstract}
Abstrakt: Ciel'om je konfrontácia archeologických prameňov z hradu Pet’uša s dobovými historickými prameňmi viažucimi sa na obec Ostrá Lúka (Stoluca), v katastri ktorej sa hrad nachádza a cez ktorú v stredoveku viedli významné obchodné cesty. Pri obci bola v stredoveku zriadená aj mýtna stanica, ktorá mohla sidlit' priamo na hrade Pet'uša alebo v jej blizkosti, pričom jej zabezpečovala ochranu. O staviteloch, majitel'och, prípadne uživatel'och hradu konkrétne informácie nevieme, nakol'ko zatial' nebol objavenýžiadny jednoznačný písomný prameň, ktorý by sme s lokalitou mohli priamo stotožnit'. Bohatá materiálna kultúra však naznačuje, že obdobie intenzívneho využivania hradu sa viaže na 14. storočie, vznik predpokladáme už koncom 13. storočia a zánik je evidentný koncom 15. storočia, resp. v prvej polovici 16. storočia.
\end{abstract}

Kl'účové slová: hrad Pet’uša - Ostrá Lúka - písomné pramene - materiálna kultúra - mýtna stanica.

\section{Pet’uša Castle: An aristocratic seat or a toll station? Comparison of archaeological and historical sources}

\begin{abstract}
This article seeks to compare archaeological sources from the Petuša castle with historical sources associated with the village of Ostrá Lúka (Stoluca), in the cadastral zone of which the castle is situated and through which major trade routes led in the Middle Ages. There was also a toll station in the village that might have been located directly in the Pet'uša castle or near it, protecting the castle. There is no relevant information about the builders, owners or users of the castle as no written records directly relating to the location have been found. However, its rich material culture indicates that the castle was most intensely used in the 14th century. It was probably constructed in the late 13th century and ceased to exist at the end of the 15th century or in the first half of the 16th century.
\end{abstract}

Key words: Pet’uša castle - Ostrá Lúka-written sources-material culture-toll station.

Zaniknutý vrcholnostredoveký hrad Pet'uša, situovaný na strednom Slovensku ned'aleko okresného mesta Zvolen, sa do povedomia verejnosti dostal v roku 1997, ked' ho do odbornej literatúry pod názvom Matčin Zámok uviedol V. Hanuliak. Na základe krátkeho sondážneho výskumu ho datoval do polovice 15 . storočia, ked' okolie Zvolena svojimi vojenskými oddielmi mocensky ovládal Ján Jiskra z Brandýsa (Hanuliak 2006, 265-269). Moderný archeologický výskum realizuje na hrade každú letnú sezónu od roku 2011 Katedra archeológie Univerzity Konštantína Filozofa v Nitre (bližšie pozri Beljak Pažinová 2017). Za sedem výskumných sezón sa podarilo preskúmat' rozsiahle časti nádvoria, hradby opevnenia, priekopu a okolité terasy; celkovo plochu s rozsahom vyše $150 \mathrm{~m}^{2}$. Zároveň sa spresnilo datovanie hradu (koniec 13. storočia - 15./16. storočie) a jeho stavebno-historický vývoj. Hrad Pet’uša doposial' nebol predmetom archívno-historického výskumu.

\section{Stručný opis hradu (obr. 1)}

Hrad má približne oválny tvar s max. rozmermi $44 \times 24 \mathrm{~m}$ a je umiestnený $\mathrm{v}$ severojužnom smere na ostrožnej polohe nad l'avým brehom rieky Hron, v nadmorskej výške vnútorného priestoru 368-372,7 m. Zachovalé časti kamenného opevnenia dosahujú v súčasnosti výšku $1,5-1,7 \mathrm{~m}$ v severnej až po $2,1 \mathrm{~m}$ v západnej a $3 \mathrm{~m}$ v južnej časti nádvoria. Koruna hradby je šikmo deštruovaná s výrazným sklonom smerom von. Hrúbka hradby sa pohybuje od 2 do $2,2 \mathrm{~m}$. Pôvodná výška opevnenia je odhadovaná na minimálne 5-6m nad terénom nádvoria. Kameň na výstavbu bol získaný zrejme pri híbení priekopy situovanej južne od hradu. Vchod do hradu ani presnú prístupovú cestu zatial' nevieme lokalizovat'.

Na nádvorí hradu má dominantnú pozíciu väčšia priehlbina lievikovitého tvaru s vystupujúcim obvodom nad terén. Ide o objekt cisterny na dažd’ovú vodu. Vyhĺbená bola do masívu skaly 
do híbky vyše $3 \mathrm{~m}$. Obloženie bolo riešené kamennými kvádrami v niekol'kých vrstvách, pričom steny i dno boli odizolované vrstvou čierneho kompaktného ílu, zamedzujúceho priesakom.

V juhovýchodnej časti nádvoria bola odkrytá čast’ kompaktného kamenného základu (základ pre drevenú budovu? vežu?), ktorý sa zatial' zdokumentoval v rozsahu takmer $4 \times 7 \mathrm{~m}$ (mocnost' $0,5 \mathrm{~m}$ ) a potvrdilo sa, že bol plynulo pristavaný k vnútornému lícu východnej hradby (obr. 2).

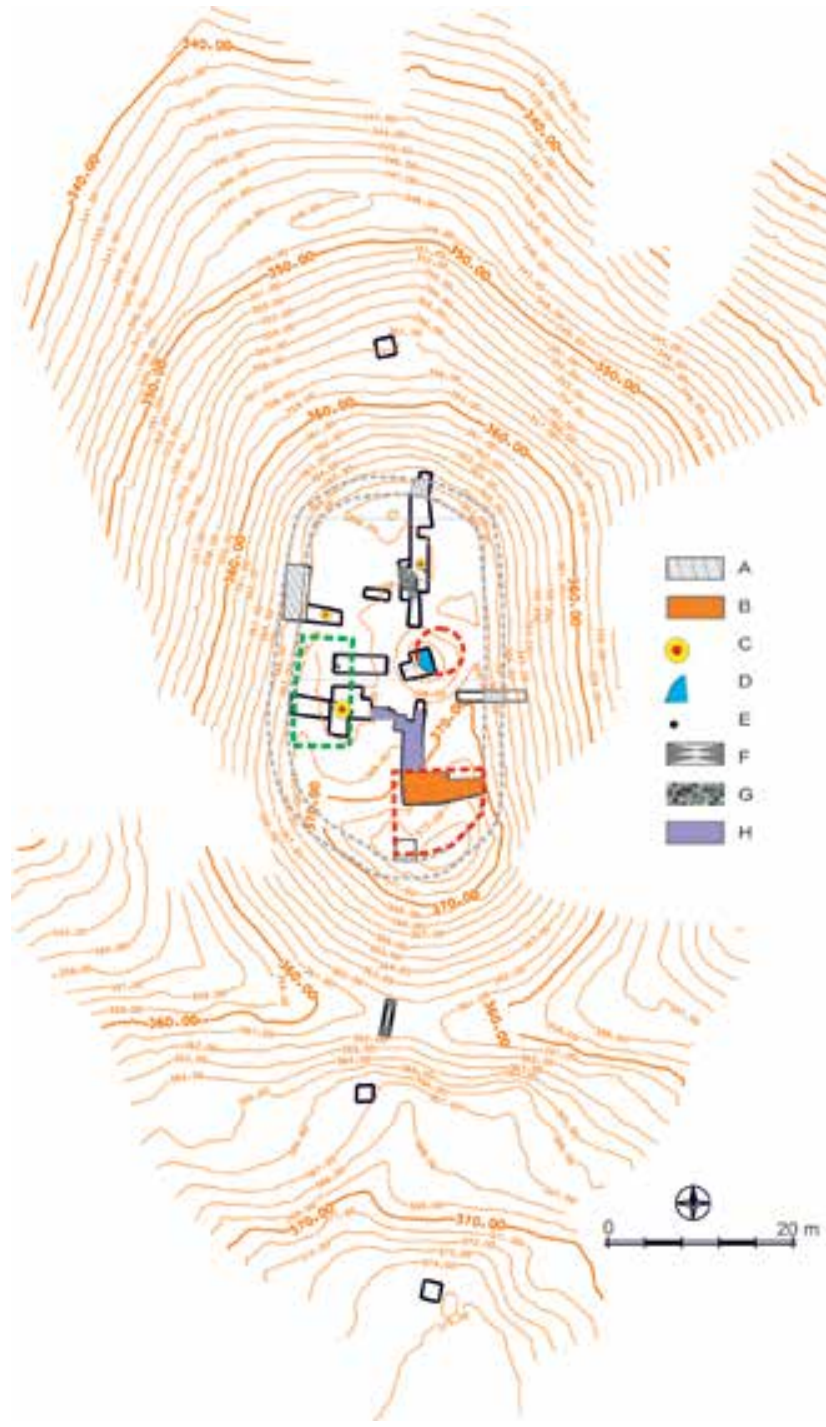

Obr. 1. Hrad Pet'uša, okr. Zvolen. Výškopis hradu s preskúmanými nehnutel'nými objektmi. A - kamenné opevnenie, B kamenný základ (drevenej veže?), C - hlinená piecka s popolom, D - kamenné opláštenie cisterny, E - kolová jama, F priekopa vytesaná do skaly, G - hutná žltá spraš (padnutá stena?), H - vyrovnané kamenné nádvorie. Prerušovaná červená farba - nehnutel'né kamenné objekty (kvadratický základ veže?, cisterna kruhového tvaru), prerušovaná zelená farba - drevohlinitá (?) stavba s pivničným priestorom vytesaným do skaly. Autori ORNTH, s. r. o.; N. Beljak Pažinová.

Abb. 1. Burg Pet'uša, Kreis Zvolen. Höhendarstellung der Burg mit untersuchten Objekten. A - Befestigung aus Stein, B Steinfundament (eines Holzturmes?), C - Lehmofen mit Asche, D - Steinummantelung der Zisterne, E - Pfahlgrube, F - in den Felsen gehauener Graben, G - dichter gelber Lössboden (eingestürzte Wand?), H - ebener Steinhof. Rot gestrichelt Objekte mit Steifundamenten (quadratisches Turmfundament?, runde Zisterne), grün gestrichelt - Holz-Lehmbau (?) mit in den Fels gehauenem Kellerraum. Erstellt von ORNTH, s.r.o.; N. Beljak Pažinová. 
V ostatných častiach hradu, prevažne pozdíž severnej a západnej hradby, stáli drevohlinité hospodárske i obytné stavby. Objavené boli aj viaceré kruhové piecky, ktoré slúžili pri vykurovaní i pri výrobných úkonoch. Identifikované boli tiež jamy po drevených koloch a pomerne plynulo vyrovnané nádvorie hradu.

\section{Hmotná kultúra}

Počas viacsezónneho výskumu sa na nádvorí hradu Pet'uša podarilo odkryt' bohatý nálezový fond, ktorý poukazuje na jeho približne dvojstoročné fungovanie. Za sedem sezón archeologického výskumu (celkovo 73 pracovných dní) bol na lokalite získaný rozsiahly nálezový súbor. Z nádvoria evidujeme takmer 25000 črepov, vyše 6000 zvieracích kostí a takmer 2000 kovových predmetov.

V prípade kovových nálezov je presnejšie datovanie často problematické, nakol'ko väčšina tvarov predmetov má dlhotrvajúci výskyt, ktorý zaberá niekol'ko storočí. Predmety objavujúce sa na hrade Pet'uša jednoznačne spadajú do obdobia vrcholného stredoveku, zrejme s jadrom výskytu v 14. storočí. Variabilita kovových predmetov je vel'ká, popri zbraniach (hrotov šípov výlučne s tŕňom) sa vyskytli aj súčasti konského výstroja, pol’nohospodárske náčinie, rôznorodé remeselnícke nástroje, nože, kovania, ozdobné predmety a mnohé d’alšie. Najväčší podiel medzi kovovými predmetmi majú stavebné kovania (klince, skoby), ktoré tvoria vyše dve tretiny všetkých nálezov. Dokladajú zároveň, že nádvorie obkolesovali početné drevené stavby (minimálne $\mathrm{v}$ jednom prípade $\mathrm{v}$ západnej časti nádvoria aj s pivničným priestorom), ktoré sa jednou stenou pravdepodobne dotýkali vnútorného líca opevnenia.

Za samostatnú zmienku stojí napr. nález železného držadla, zrejme z kotlíka (obr. 3:1), ktorý sa našiel priamo $v$ popole uprostred hlinenej kruhovej piecky s najväčším priemerom v západnej časti nádvoria hradu. Analogické nálezy nachádzame na viacerých ikonografických prameňoch

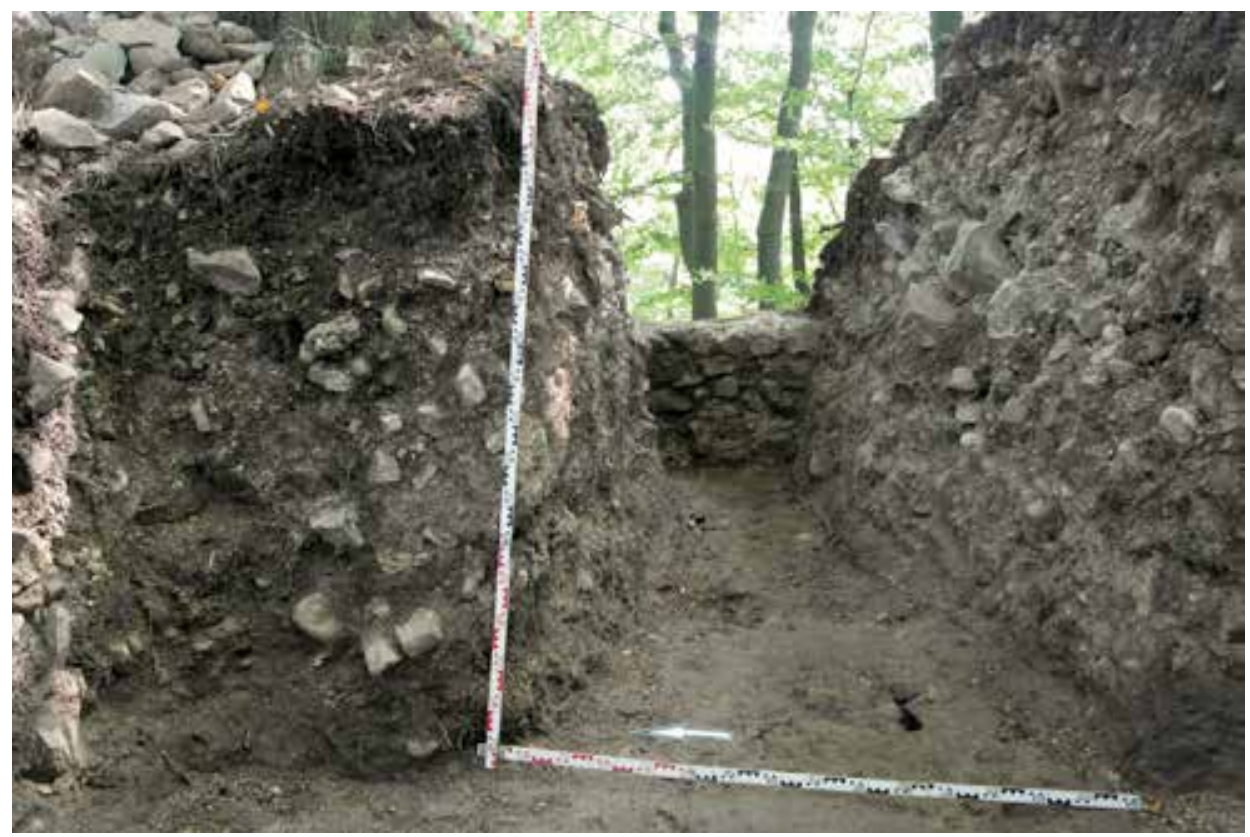

Obr. 2. Hrad Pet’uša, okr. Zvolen. Kompaktný kamenný základ (budovy?) zdokumentovaný v južnej časti nádvoria, priliehajúci k vnútornému lícu východného opevnenia. Foto N. Beljak Pažinová.

Abb. 2. Burg Pet’uša, Kreis Zvolen. Im Südteil des Hofes dokumentiertes und an der Innenflucht der Ostbefestigung anliegendes kompaktes Steinfundament (eines Gebäudes?). Foto N. Beljak Pažinová. 

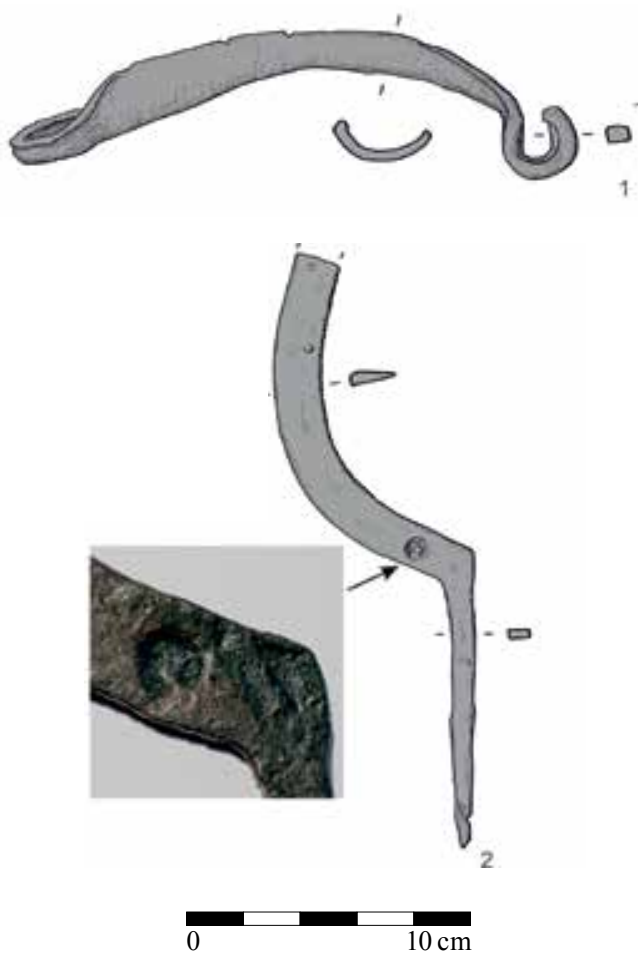

Obr. 3. Hrad Pet'uša, okr. Zvolen. Výberové železné predmety: 1 - držadlo z kotlíka, 2 - kosák s vyrazenou značkou. Kresba D. Zeleňáková; foto N. Beljak Pažinová. Abb. 3. Burg Pet'uša, Kreis Zvolen. Ausgewählte Eisengegenstände: 1 - Henkel eines Kessels, 2 - Sichel mit eingestanzter Marke. Zeichnung D. Zeleňáková; Foto N. Beljak Pažinová.

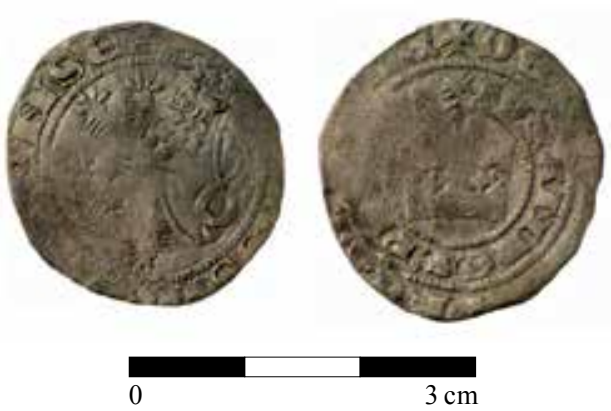

Obr. 4. Hrad Pet'uša, okr. Zvolen. Pražský groš s razbou Jána Luxemburského, 1. polovica 14. storočia. Foto N. Beljak Pažinová.

Abb. 4. Burg Pet'uša, Kreis Zvolen. Prager Groschen mit Prägung von Johann von Luxemburg, erste Hälfte 14. Jahrhundert. Foto N. Beljak Pažinová. (napr. Treue 1965, 132, Taf. 146; Scappi 1622, $87,89,92,100)$. Rovnako výnimočný je nález železného kosáka s razenou značkou výrobcu - majstra (?) na päte čepele (obr. 3:2), objavený v kultúrnej vrstve nad kompaktným kamenným základom veže (?) v juhovýchodnej časti areálu. Značenie sa nachádza na zadnej strane čepele kosáka, pričom ide o okrúhlu razbu s hlavným motívom vo vnútri kruhu, ktorý je plasticky rozdelený na štyri trojuholníkové časti. Ostrie kosáka má trojuholníkový prierez a je opatrené zásekmi na spodnej strane. Zaujímavé je, že ide o kosák určený pre praváka (Borzová 2016, 68), napriek tomu Žatec pri práci značku nevidel, nakol'ko bola na opačnej strane. Takéto situovanie razby je raritou. Presnú analógiu objaveného kosáka zatial' z priestoru strednej Európy nepoznáme, avšak podobné vrcholno- a neskorostredoveké značené jedince spomína R. Müller (1982, 42, 57, 129, 131, 136, 166, 199, 271, 316, 319, 343, $370,374,401-403)$.

Z farebných kovov je významný nález falzifikátu strieborného denára uhorskej král'ovnej Márie z Anjou, ktorého originály boli razené v roku 1383 (Beljak Pažinová 2017, 463, obr. 10). Unikátna je aj takmer nepoškodená dvojdielna olovená plomba (Beljak Pažinová 2017, 463, obr. 11) z textilného (lanového?) tovaru z Benátok z konca 14. storočia, ktorá bola obojstranne zdobená. Podobnú razbu plomby zo strednej Európy zatial' nepoznáme.

K novým nálezom patrí dobre zachovaný strieborný pražský groš (obr. 4) s razbou Jána Luxemburského z prvej polovice 14. storočia (1310-1346). Na rube (reverz) sa nachádza obraz českého heraldického leva a opis GROSSI PRAGENSES (groš pražský). Na lícnej strane (averz) sa nachádza česká král’ovská koruna, opis mena panovníka (IOHANNES PRIMUS) a nápis DEI GRATIA REX BOEMIE (Z Boži milosti král' český). Nález môže mat' priamu súvislost' so stredovekou mýtnou stanicou, ktorú pri Ostrej Lúke spomínajú písomné pramene. V okolí hradu sa nachádzajú viaceré historické cesty (obr. 5; Pažinová a kol. 2013, 157, 160, obr. 4,8), ktoré v minulosti slúžili obchodníkom prichádzajúcim na trhy do Zvolena, resp. širšieho okolia. Groš mohol stratit' obchodník, ktorý mal v striebre uloženú čast' svojho imania. Prípadne peniaz súvisel priamo s vyberaním trhového, resp. cestného 

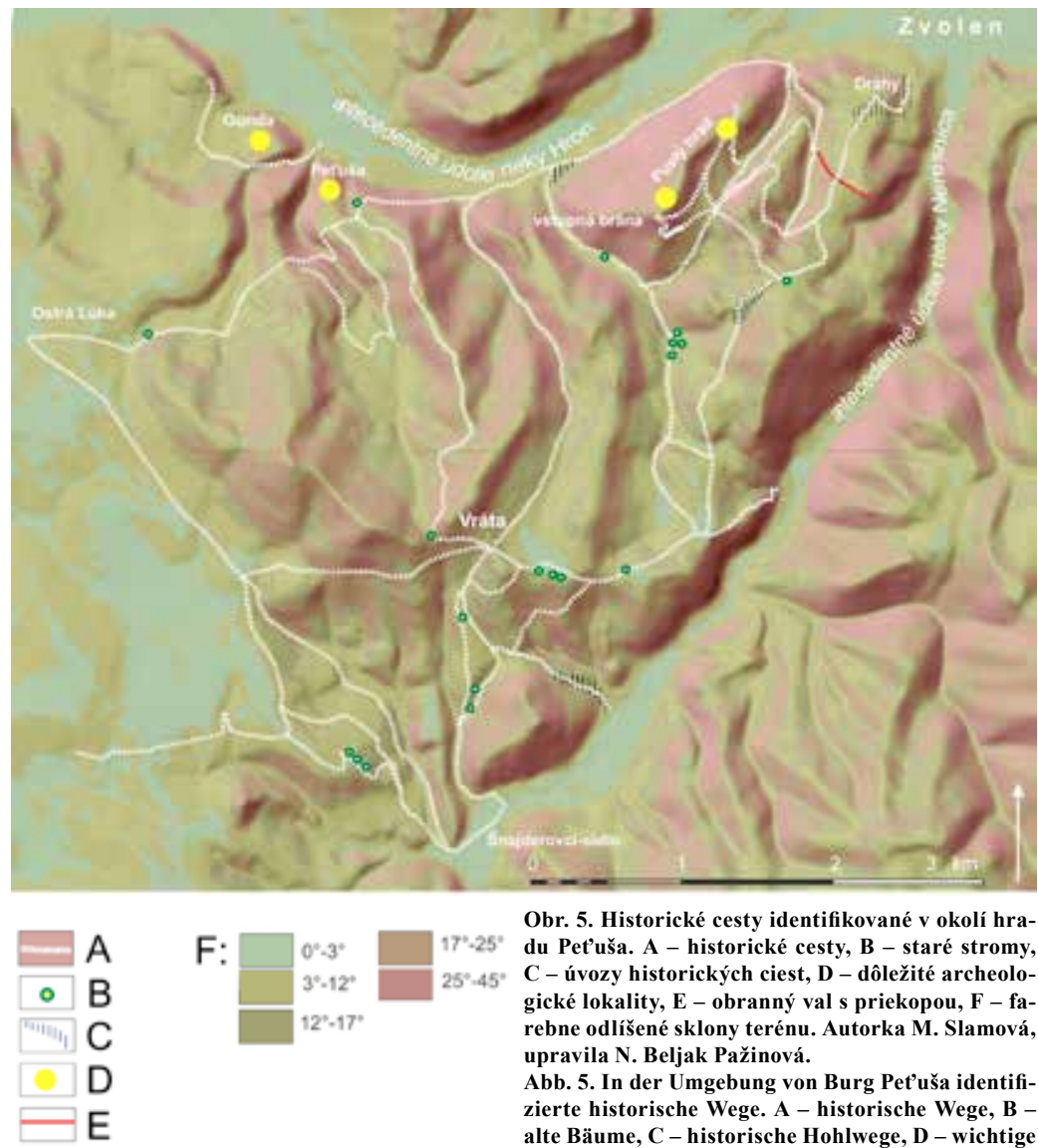

Obr. 5. Historické cesty identifikované v okolí hradu Pet'uša. A - historické cesty, B - staré stromy, C - úvozy historických ciest, D - dôležité archeologické lokality, E - obranný val s priekopou, F - farebne odlíšené sklony terénu. Autorka M. Slamová, upravila N. Beljak Pažinová.

Abb. 5. In der Umgebung von Burg Pet'uša identifizierte historische Wege. A - historische Wege, B alte Bäume, C - historische Hohlwege, D - wichtige archäologische Fundstellen, E - Verteidigungswall mit Graben, F - farblich unterschiedene Geländeneigungen. Erstellt von M. Slamová, bearbeitet von N. Beljak Pažinová.

mýta. Zaujímavé, že zo Zvolena pochádza aj najväčší depot pražských grošov Karola IV. (1 groš) a Václava IV. (22 grošov) v širšom regióne (Švec 2011). Nájdené boli náhodne ako jeden celok v blízkosti severnej vstupnej brány do stredovekého mesta. Ich presné určenie času uloženia do zeme nie je, žial', jasné, najpravdepodobnejší je začiatok 15. storočia, vylúčit' však tiež nemožno staršie deponovanie. Analogicky najbližší nález pražského groša s razbou Jána Luxemburského bol objavený na strednom Slovensku na hrade Luupča (Budaj 2006, 303, 304). Na Slovensku evidujeme celkovo len okolo dvoch desiatok lokalít s nálezmi pražských grošov Jána Luxemburského, pričom 15 lokalít uvádza do roku 2003 M. Budaj (2005, 137-148).

Keramický súbor z hradu Pet’uša z výskumných sezón 2011 až 2014 (vrátane selektívneho výberu zo sezón 2015 a 2016) komplexne spracoval a vyhodnotil v rámci diplomovej práce D. Javorek (2017). Hrad Pet'uša je situovaný na pomyselnom priesečníku viacerých keramických okruhov vrcholno- a neskorostredovekej keramiky. Najväčšia čast' nálezov z hradu (okolo 90\%) prislúcha keramike s farebným črepom (hlina s vysokým obsahom farbiacich kysličníkov), ktorá je typická pre oblast' stredného Slovenska, ale zaznamenaná bola aj na juhozápade, severozápade a severe územia. Pre juhozápadné Slovensko charakteristická sivá keramika je na hrade zastúpená necelou desatinou z celku. Na lokalite bola prítomná aj biela a biela malovaná keramika (cca 2-3\%), ktorej okruh výskytu zaberá juh stredného Slovenska, kde sa začala objavovat' od 
polovice 13. storočia, dominovala však hlavne v 14. storočí a vyskytla sa aj neskôr (Hoššo 1971, 69; 1983, 220). V prípade nálezov z hradu Pet’uša boli aplikované hlavne farby hnedooranžová, hnedočervená a sivá, pričom z výzdobných motívov sa vyskytli pásové vzory a bodky (obr. 6:1). Analogické jedince poznáme $\mathrm{z}$ viacerých miest uhorského královstva (obr. 6:2, 3).

Spôsob modelácie nádob $\mathrm{z}$ hradu odráža datovanie získaného keramického súboru. $\mathrm{V}$ 13. storočí a taktiež aj $\mathrm{v}$ priebehu 14. storočia boli nádoby $\mathrm{z}$ ručného hrnčiarskeho kruhu strhávané, o čom svedčí viacero špecifických znakov na dnách nádob, mimo iného i výskyt obvodovej lišty, resp. zachovalost' plastickej značky. Takéto jedince dominovali aj v súbore z hradu Pet'uša. Vyzdvihnút' treba plastickú značku tvaru osemramennej ružice (obr. 7:1), ktorá má analógie v materiáli z blízkeho Pustého hradu vo Zvolene (Hanuliak 1999, 355, tab. 3:2; Beljak a kol. 2014, obr. 124:7) a datovaná je do 13. storočia. Väčšina zachovaných značiek na lokalite mala tvar rovnoramenného kríža v kruhu (obr. 7:3-6). Tieto typy značiek na dnách sú už celkovo prejavom o niečo mladšieho hrnčiarstva a ich výskyt je doložený od 13. storočia naprieč celým 14. storočím až po niektoré prípady z 15. storočia (Hoššo 1985, 252). V súbore sa objavili
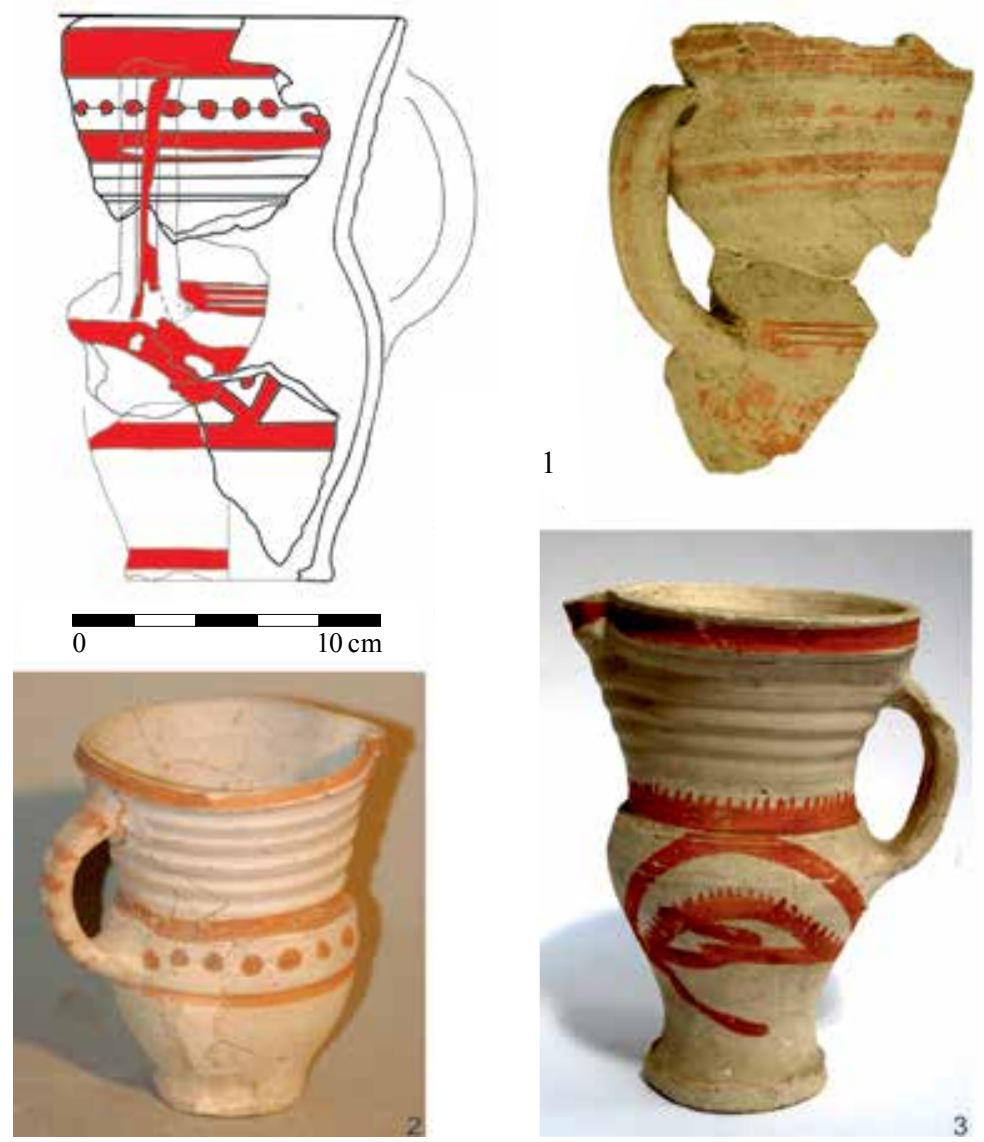

Obr. 6. Hrad Pet’uša, okr. Zvolen. 1 - rekonštruovaný džbán bielej mal’ovanej keramiky zo 14. storočia z nádvoria hradu. Kresba D. Zeleňáková; foto N. Beljak Pažinová. Analogické nálezy: 2 - z mad’arského Visegrádu, 3 - z Vácu. Podl’a BuzásLászlovsky a kol. 2013, 241, obr. 8, 9.

Abb. 6. Burg Pet'uša, Kreis Zvolen. 1 - rekonstruierter Krug mit weiß bemalter Keramik aus dem 14. Jahrhundert vom Burghof. Zeichnung D. Zeleňáková; Foto N. Beljak Pažinová. Analoge Funde: 2 - aus dem ungarischen Visegrád, 3 - aus dem ungarischen Vác. Nach Buzás-Lászlovsky a kol. 2013, 241, Abb. $8,9$. 
aj netypické značky pripomínajúce písmeno „P“v kruhu (obr. 7:2) alebo zložitejšia kvadratická značka (obr. 7:7).

V závere vrcholného stredoveku (druhá polovica 14. storočia a najmä v 15. storočí) bola už vo viacerých oblastiach rozšírená technika vytáčania na rýchlorotujúcom, nožnom kruhu, z ktorého sa nádoby oddel'ovali zrezávaním. V spracovanom súbore boli stopy po zrezávaní dna evidentné len u minimálneho počtu jedincov (necelé dve desiatky dien).

Relatívna chronológia keramiky objavenej na nádvorí hradu je zachytená hlavne na základe sledovania profilácie okraja nádob, ktorá najlepšie zachytáva meniaci sa vývojový trend. Jednoznačne v súbore prevládajú rôzne hrncovité tvary (tvoria vyše tri štvrtiny súboru), $v$ menšej miere sa objavujú džbány a pokrievky. Minimálne zastúpenie majú fl'aše, poháriky a misy. Okraje nádob boli zachytené na štvrtine typických fragmentov, ktoré predstavujú približne pätinu všetkých keramických nálezov. V súbore boli zastúpené viaceré varianty jednoduchých profilovaných okrajov (13. storočie; 13./14. storočie), viacnásobných profilovaných okrajov (koniec 13. storočia, ale hlavne 14. storočie), zatiahnutých okrajov (13.-14. storočie, prvá polovica 15. storočia), nahor vytiahnutých a rímsovitých okrajov (koniec 13. storočia, ale hlavne
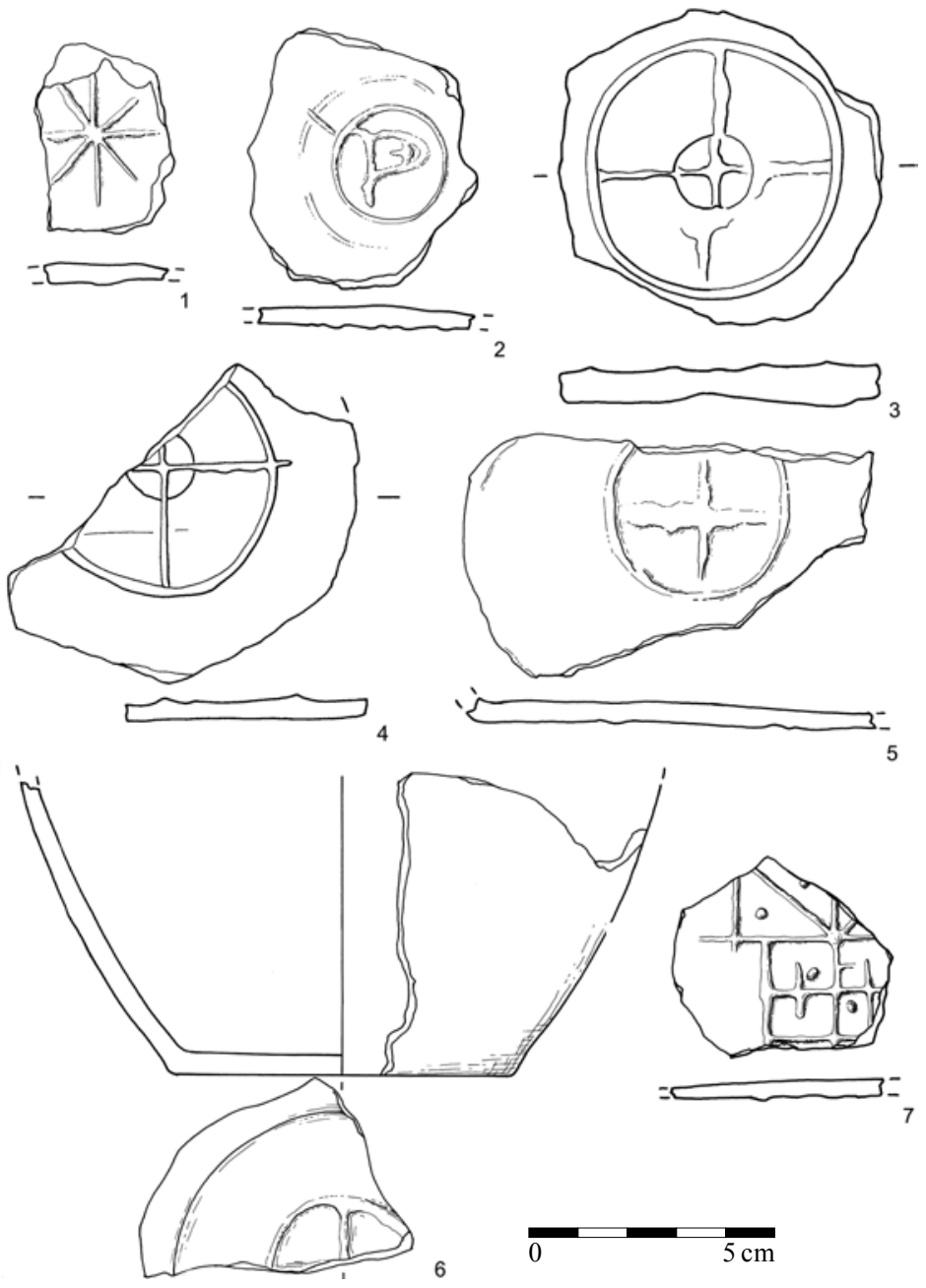

Obr. 7. Hrad Pet'uša, okr. Zvolen. Dná zdobené značkami. Kresba D. Zeleňáková.

Abb. 7. Burg Pet’uša, Kreis Zvolen. Mit Marken verzierte Gefäßböden. Zeichnung D. Zeleňáková. 
14. storočie; prvá polovica 15. storočia), manžetovitých okrajov (14./15. storočie) a aj zosilnené okraje s obežnou lištou (14.-15. storočie). Do najstaršieho horizontu (13. storočia; 13./14. storočie) na hrade je možné radit' esovito profilované ústia s najčastejšie prežliabnutými či prištipnutými okrajmi (obr. 8:1-4), pričom ústie sa postupne vyvíja do lievikovitej profilácie. Druhý horizont (13./14. storočie; 14. storočie) predstavujú lievikovito profilované ústia s nahor vytiahnutými, prežliabnutými, zatiahnutými či rôzne profilovanými okrajmi (obr. 8:5-7). Tretí horizont (2. polovica 14. storočia; 15. storočie) charakterizujú viacnásobne profilované ústia, mnohokrát s dutou profiláciou, s vysokou variabilitou tvarov okraja (obr. 8:8, 9, 11-13). Charakteristickým reprezentantom hrncov tohto mladšieho úseku sú napríklad manžetovité okraje (obr. 8:10).

S chronologickým vývojom keramiky sú spájané aj zmeny ornamentiky (výzdobných motívov). V zdobení dominuje rytá výzdoba v podobe tenších rýh alebo (širších) žliabkov na pleciach nádob, ojedinelé sú viacnásobné línie pokrývajúce zrejme celé telo nádoby (závitnicový ornament). Tento najrozšírenejší druh výzdoby sa na keramike objavuje celé 13. a 14. storočie. V 15. storočí variabilita v situovaní rytej výzdoby ubúda a objavuje sa hlavne na pleciach v podobe širokých žliabkov (Hoššo 1983, 217). V súbore sa vyskytovali jemné ryté línie aplikované aj pomerne nahusto (obr. 9:3, 6, 9), resp. vyhotovené v podobe rytej závitnice. Husté žliabkovanie, vytvárajúce obraz tzv. rebrovania, bolo zachytené na sivej keramike a datované je do polovice 14. storočia. V období 14. storočia zaniká zdobenie vlnovkou, ktoré sa na lokalite vyskytlo na jedincoch farebnej a sivej keramiky, aplikované pod okrajom, na pleciach a vydutine (obr. 8:9; 9:4, 5, 9). Zaujímavý bol výskyt typického staršieho výzdobného motívu v podobe vrypov na hrdlách a pod okrajom nádob farebnej keramiky (obr. 8:13; obr. 9:2). Ich aplikácia sa v závere 13. storočia vytráca (Beljak a kol. 2014, 155). Do 13. storočia, prípadne začiatku 14. storočia vieme zaradit' aj šikmé zárezy objavujúce sa výlučne pod okrajmi a na hrdlách v podobe istých „zväzkov“, pravdepodobne naprieč celým obvodom (obr. 9:1). Taktiež radielkovú výzdobu (obr. $9: 7,8)$ vieme datovat' do 13 . storočia s pretrvaním aj začiatkom nasledujúceho storočia. Naopak, mladý výzdobný element predstavuje v súbore pretláčaný prvok aplikovaný na pohári sivej keramiky (obr. 9:10, 11). Obyčajne sú nádoby s takýmto prvkom datované do druhej polovice 15. storočia až prvej polovice 16. storočia (napr. Hoššo 1984, 135, tab. IV:2; Matějková 2014, 100; Blažková 2013, 192, 216; Španihel 2014, 170, tab. VI:1).

Špecifický a ojedinelý v celom súbore je bordovo glazovaný pohárik (čaša), pod okrajom zdobený plastickým kruhovým terčíkom v tvare maliny (obr. 10:1), ktorý je dokladom dial'kových kontaktov (import z rakúskych dielní). Jeho analógie nachádzame nielen na území Uhorského král'ovstva od druhej polovice 14. storočia až po prelom 15./16. storočia (napr. Kocsis 2016, 279, tab. 4:1; Mordovin 2016, 324, obr. 3:2; Blažková-Dubská 2007, 20, obr. 9:7; Holl 1963, 367, obr. 49; 358, obr. 51; Březinová-Samuel a kol. 2007, 65, obr. 82:c, d).

Na záver je potrebné spomenút' aj krehký fragment bezfarebného skla, pochádzajúci zrejme z čaše/pohárika. Zachovaná čast' obsahuje úzku obvodovú plastickú lištu (deliacu lievikovité ústie od samotného tela jemne sudkovitého tvaru), pričom telo bolo pôvodne zdobené sklenenými perlami/nálepmi (zachoval sa jeden kus) s vytiahnutou sklenenou kvapkou (obr. 10:2). Takýto typ skla je datovaný na našom území hlavne do 14. storočia s výskytom aj v nasledujúcom storočí (najnovšie Sedláčková et al. 2014).

\section{Archívno-historický výskum}

Poloha hradu Pet'uša, umiestneného na miernej vyvýšenine v úzkom údolí nad tokom Hrona, dovol'uje celkom logicky predpokladat', že ide o strážny hrad, ktorého najdôležitejšou úlohou bola kontrola tamojšej cestnej a vodnej komunikácie, spojená azda i s výberom mýta. Tento predpoklad podporuje umiestnenie opevnenia v blízkosti hronského brodu (Maliniak 2009, 216-218), tesne za okrajom chotára mesta Zvolena, ktorého meštania boli oslobodení od mýta $\mathrm{v}$ rámci celého Uhorska.

Písomné pramene nevylučujú skutočnost', že hrad Pet’uša bol v období stredoveku spojený s výberom mýta. V tom prípade môžeme objekt stotožnit's ostrolúckou mýtnou stanicou, 

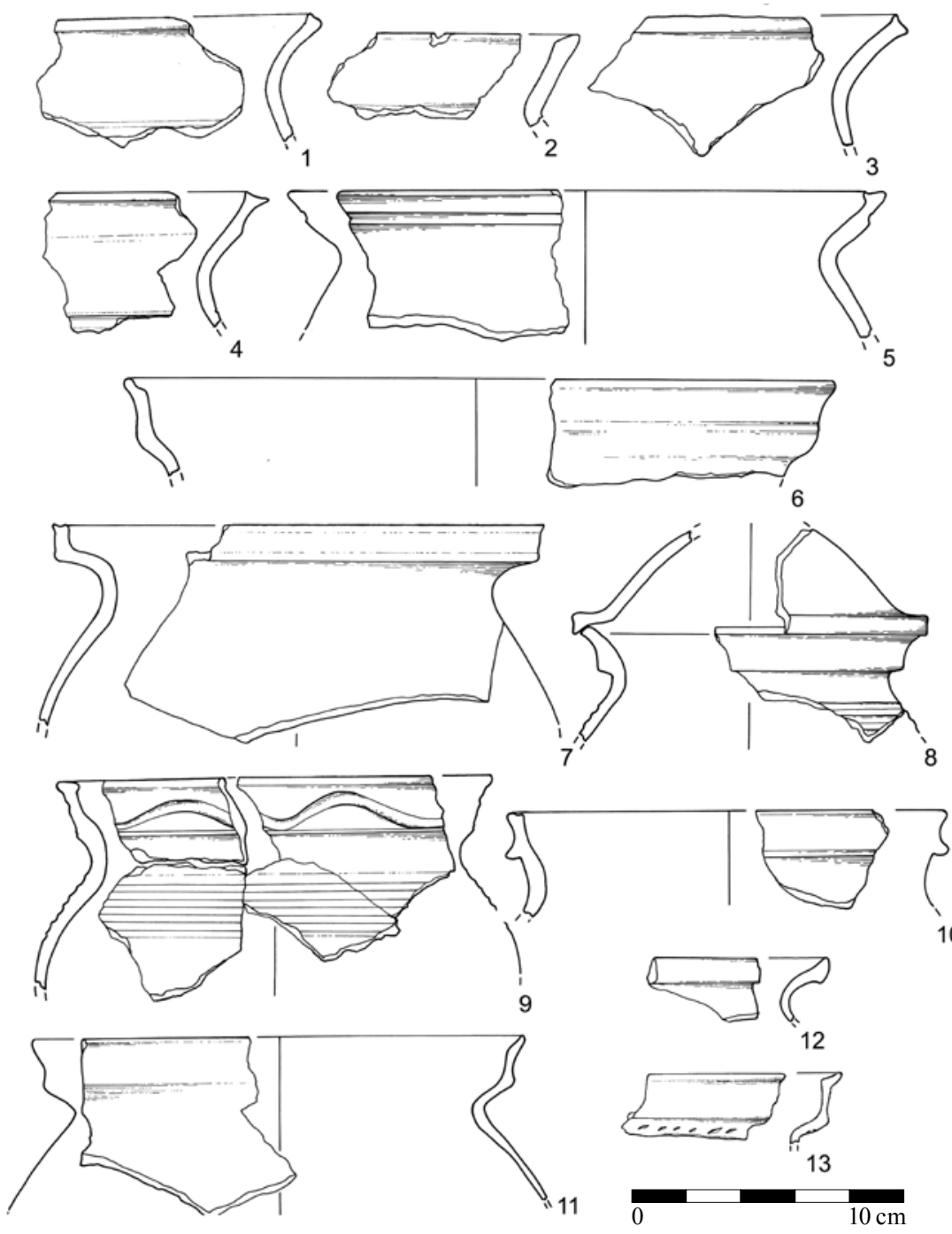

Obr. 8. Hrad Pet'uša, okr. Zvolen. Variabilné okraje hrncov vrcholnostredovekej keramiky. Kresba D. Zeleňáková. Abb. 8. Burg Pet'uša, Kreis Zvolen. Topfrandvarianten hochmittelalterlicher Keramik. Zeichnung D. Zeleňáková.

v latinských prameňoch označovanou zvyčajne ako tributum. Údaje o tejto mýtnej stanici sú v stredovekých písomných prameňoch len vel'mi strohé. Mýtna stanica je prvýkrát listinne doložená v roku 1393. Na žiadost' zvolenského richtára a prísažných vtedy uhorský panovník Žigmund Luxemburský svojou výsadnou listinou potvrdil, že kupci prichádzajúci na výročný zvolenský jarmok, konaný na budínsky spôsob, sú oslobodení od platenia mýta v okruhu dvoch míl' od mesta (Ragač 1998, 13-14). Výsadná listina aj presne vypočítava, že spolu išlo o päticu mýtnych staníc, umiestnených v Dobrej Nive, Ostrej Lúke, Pliešovciach, Trnávke pri hrade Šášov a vo Zvolenskej Slatine (Ragač 1998, 14). Spomínaná panovnícka listina z roku 1393 tiež uvádza, že išlo o tradičné mýtne miesta, kde sa zvyklo vyberat' mýto už predtým - exigi consueta.

$\mathrm{V}$ neskorších desat'ročiach sa $\mathrm{s}$ ostrolúckou mýtnicou $\mathrm{v}$ písomných prameňoch stretávame opakovane. Mýtnica vystupuje v panovníckych konfirmáciách zvolenských trhových 

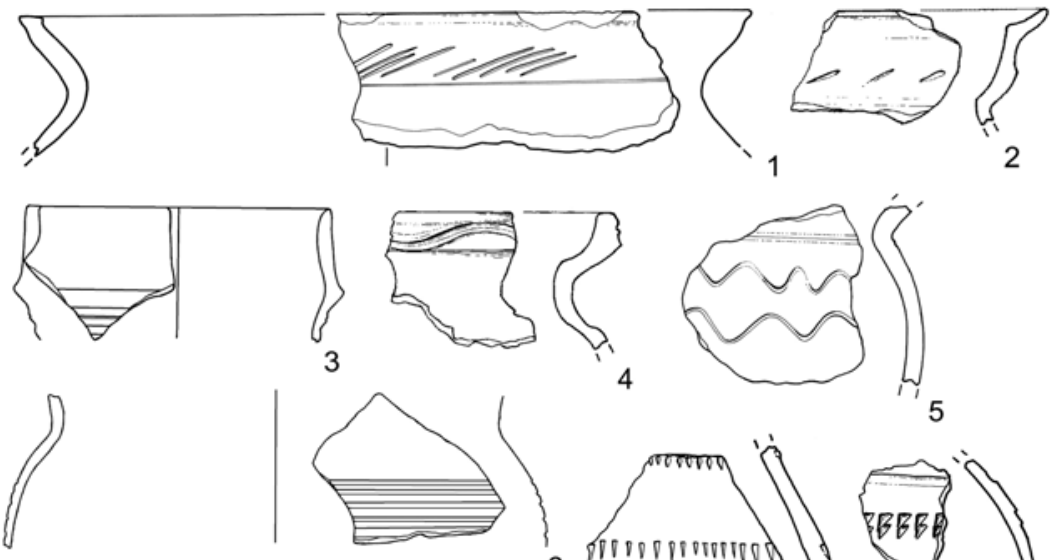

3

4

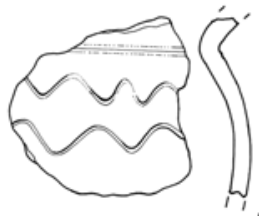

5

6
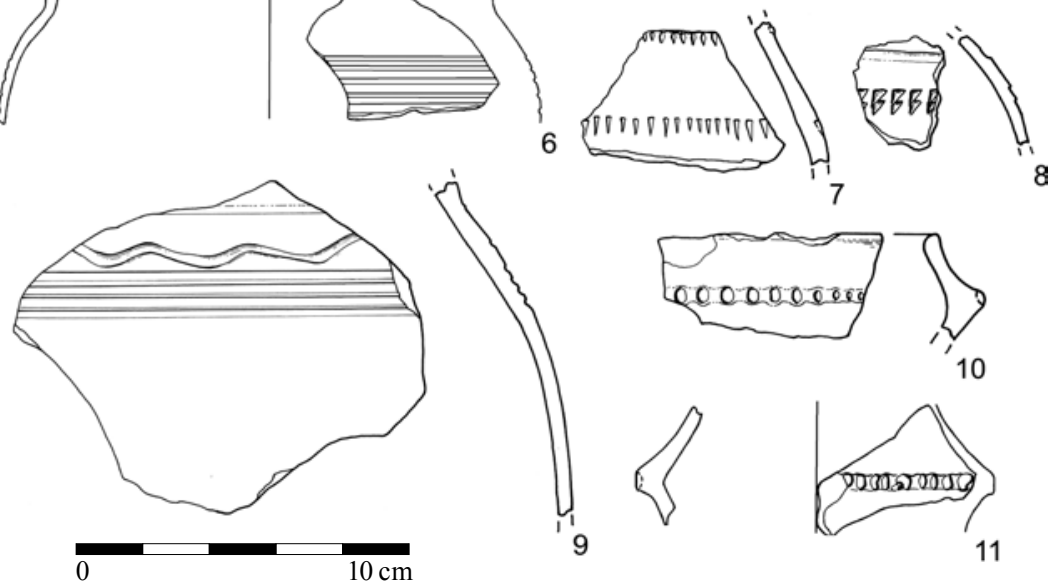

11

Obr. 9. Hrad Pet'uša, okr. Zvolen. Rôzne výzdobné prvky aplikované na nádobách. Kresba D. Zeleňáková. Abb. 9. Burg Pet'uša, Kreis Zvolen. Verschiedene an den Gefäßen applizierte Zierelemente. Zeichnung D. Zeleňáková.

privilegiálnych listín z rokov 1412, 1478 a predbežne naposledy v listine uhorského král’a Ludovíta II. Jagellonského z roku 1519 (MNL ${ }^{1}$ DF, 268 920, 268 921, 268 965).

Ostrolúcka mýtna stanica bola od stredoveku súčastou hradného panstva Dobrá Niva. Zrejme to súviselo aj s držbou časti Ostrej Lúky dobronivskými kastelánmi v druhej polovici 15. storočia. V roku 1464 daroval král' Matej Korvín polovicu Ostrej Lúky dobronivskému kastelánovi Benediktovi z Turca (Turóczy, de Thurocz) (MNL DL, 108 177). Už predtým tú istú polovicu Ostrej Lúky v roku 1457 vlastnil bratislavský kastelán Ondrej Paukirchen (MNL DF, 254 190). Od roku 1515 dobronivské hradné panstvo vlastnili uhorské magnátske rody - Frangepánovci, Perényiovci a potom palatín Štefan Verbőczy. V tomto období bola polovica Ostrej Lúky s mýtnicou súčastou panstva (MNL DL, 75 500, 72 177). Ako príslušenstvo dobronivského hradného panstva je ostrolúcka mýtnica uvádzaná až do roku 1548 - Ibidem est Theloneum (MNL E, 158, Fasc. 7, 505-524). V ranonovovekom období však už bola evidentne opustená a neprinášala dobronivskému panstvu žiadne reálne príjmy.

V 16. storočí ostrolúcka mýtnica definitívne zanikla, nakol'ko sa s ňou neskôr už v písomných prameňoch nestretávame. Dôvodov zániku bolo zrejme viac. Okrem tureckej hrozby, aktuálnej od 40. rokov 16. storočia, a vážneho narušenia obchodných vzt'ahov v regióne bolo d'alším vel'kým problémom skúmanej mýtnice jej umiestnenie. Podl’a historických kartografických

1 Fotokópie a originály stredovekých a novovekých častí rodových archívov sú uložené v Mad’arskom národnom archíve v Budapešti (Magyar Nemzeti Levéltár - skratka MOL; sekcia Archív listín / Diplomatikai Levéltár - skratka DL; sekcia Fenyképgyüjtemény / Fotoarchív - skratka DF; sekcia Magyar Kamara Archívum / Archív Uhorskej komory - skratka E). Čísla uvádzané za názvom prameňa zodpovedajú číslovaniu archívneho prameňa (inventárne číslo). Dostupné aj na internete: https://archives.hungaricana.hu/hu/charters/, cit. 26. 11.2017. 

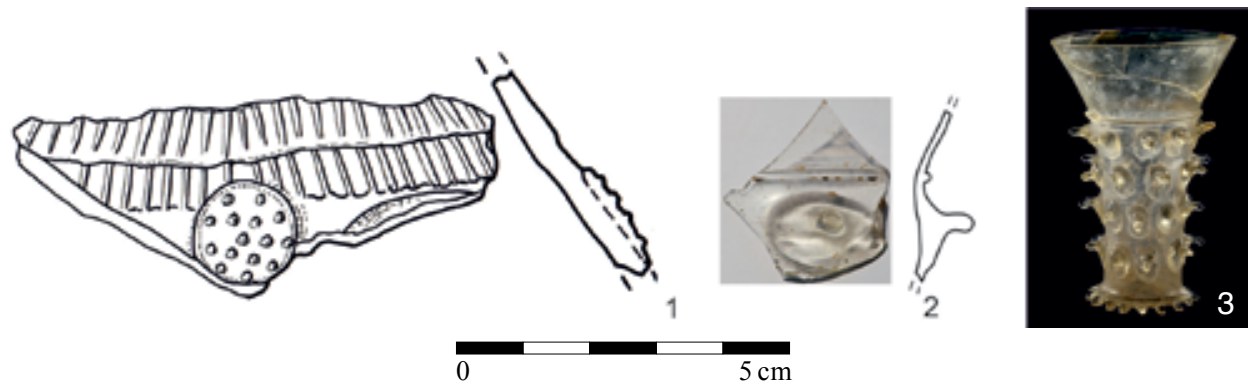

Obr. 10. Hrad Pet’uša, okr. Zvolen. 1 - bordovo glazovaný fragment čaše s plastickým výzdobným prvkom v podobe maliny, 2. polovica 14. storočia - 15. storočie, 2 - fragment bieleho skleneného pohárika s motívom sklenenej perly s vytiahnutou kvapkou, 14. storočie. Kresba D. Zeleňáková; foto N. Beljak Pažinová. 3 - analogický sklenený pohár z Talianska, 14. storočie. Podl'a Whitehouse 2010, fig. 87.

Abb. 10. Burg Pet'uša, Kreis Zvolen. 1 - bordeauxrot glasiertes Becherfragment mit plastischem, himbeerförmigem Zierelement, zweite Hälfte 14. Jahrhundert - 15. Jahrhundert, 2 - Fragment eines farblosen Glaspokals mit Glasperlenmotiv und langgezogenem Tropfen, 14. Jahrhundert. Zeichnung D. Zeleňáková; Foto N. Beljak Pažinová. 3 - analoger Glaspokal aus Italien, 14. Jahrhundert. Nach Whitehouse 2010, fig. 87.

dokumentov z druhej polovice 18. storočia (prvé vojenské mapovanie) totiž hlavná obchodná cesta do oblasti stredoslovenských banských miest viedla po opačnej strane údolia Hrona a smerovala na Zvolen a Banskú Bystricu cez masív Stráží. Odbočka z hlavnej cesty v novovekom období viedla do Zvolena cez prievoz (brod?) na Hrone v Gunde a popod opustenú Pet’ušu a rieku Slatina prekračovala zrejme pod Pustým Hradom po drevenom moste, ktorý je doložený už v neskorostredovekom období (Ragač 1998, 11). Predpokladáme, že hronský prievoz v Gunde je mladší a cesta pôvodne prekračovala rieku Hron niekde v okolí ostrolúckej mýtnej stanice. Geografickú oblast', ktorú ostrolúcka mýtnica reálne obsluhovala, limitovala d’alšia blízka, o niečo južnejšie ležiaca verejná komunikácia, vedúca do Zvolena z Banskej Štiavnice. Uvedená komunikácia viedla údolím Jesenice, patriacim do zvolenského mestského chotára, popri opačnej strane masívu Pustého Hradu. Táto obchodná cesta údolím Jesenice bola navyše „slobodná“, bez existujúcich mýtnych staníc po celej jej trase.

Práve poloha ostrolúckej mýtnej stanice bola zrejme najdôležitejším dôvodom jej zániku. Výrečná z tohto uhlu pohl'adu je listina uhorského palatína Vavrinca Héderváryho, pochádzajúca z 8. decembra 1437 (MNL DF, 254 203). Na základe žiadosti šl'achtica Bartolomeja z Bacúrova, prednesenej na stoličnej kongregácii Zvolenskej stolice v mene poddaných z obcí Bacúrov, Breznička, Budča, Gunda, Ostrá Lúka, sa zvolenská stolica zaoberala otázkou ich oslobodenia od mýta v rámci Zvolenskej stolice pri ich obchodných cestách do Banskej Bystrice, kam dovážali najmä potraviny a veci dennej potreby. Zvolenské stoličné orgány sa rozhodli žiadosti vyhoviet' a oslobodili obyvatel'ov uvedených obcí od platenia mýtnych poplatkov na území celej stolice, čo palatín prítomný na kongregácii svojou listinou schválil. Toto z hospodárskeho hladiska významné panovnícke privilégium ochraňovali od stredoveku vo svojom rodovom archíve Ostrolúcki z Ostrej Lúky. V roku 1483 si dal šlachtic Demeter z Ostrej Lúky spomínanú listinu z roku 1437 tramzumovat' hodnovernému miestu šažského konventu (MNL DF, 254 203). Uvedeným privilégiom sa vyhli plateniu mýta takmer všetci obyvatelia žijúci v okolí ostrolúckej mýtnice.

Aspoň v teoretickej rovine je potrebné počítat' aj s možnost'ou, že stavebníkom hradu Pet'uša mohol byt člen starobylého šlachtického rodu Ostrolúckych z Ostrej Lúky. Jeho zakladatel' Zima (Zyma) sa ako hudobník - píštalkár pohyboval v blízkosti uhorského krála Ladislava IV. a za odmenu získal v roku 1289 majetkovú donáciu (bližšie Beljak Pažinová 2017, 462-463). Jej situovanie hned' vedl'a Zvolenského (Pustého) hradu jasne napovedá, že král'ovi slúžil aj tam. Centrom rodových majetkov sa stala už existujúca Ostrá Lúka, kde rod v období stredoveku fundoval aj dnes zaniknutý farský kostol. Ostrolúckym sa však z králom darovaného rodového 
majetku nepodarilo vytvorit' rozsiahlejšie feudálne panstvo. Jeho hlavnú čast' sa síce rodu Ostrolúckych podarilo udržat' až do prvej polovice 20. storočia, ale silní a majetkovo stabilizovaní susedia - mesto Zvolen a hradné panstvá Zvolen a Dobrá Niva im nedali možnost' rozšírit' rodové majetky, tvorené niekol'kými malými pol'nohospodárskymi obcami, na ich úkor. O komplikovaných sporoch so susedmi svedčí aj listina z roku 1346. Zymov syn magister Ján sa vtedy sporil s príbuznými zvolenského mýtnika magistra Otmara (MNL DF, 254 168; MNL DF, 254 210). V Ostrej Lúke sa navyše rodu Ostrolúckych nepodarilo okrem pol’nohospodárskej výroby naštartovat' aj iné, ekonomicky výhodnejšie aktivity. Naopak, pod tlakom špecifického uhorského zvykového práva, ked' boli dedičmi vo všeobecnosti všetci potomkovia šlachtických rodov vrátane dcér (inštitúcia tzv. dievčenskej štvrt'ky), sa začala majetková doména rodu Ostrolúckych už v priebehu 14. storočia drobit'. Okrem dodnes existujúcej osady Gunda sa začalo postupne na menšie delit' aj jadro domény - obec Ostrá Lúka. Podl’a listiny z roku 1423 sú doložené aj jej časti, tzv. Horná Ostrá Lúka - ffelse Oztroluka a tzv. Malá dedova? Ostrá Lúka - Kysdedoztroluka (MNL DF, 254 178). Majetkový diel v chotári obce v neskorom stredoveku vlastnilo aj dobronivské hradné panstvo. Majetkové spory a del'by rodu nám dovol'ujú získat' aspoň základné informácie aj o rodovom sídle v Ostrej Lúke. V listine z roku 1418 je toto sídlo označené ako šlachtická kúria - curia. Predpokladáme, že kúria bola umiestnená v blízkosti spomínaného zaniknutého kostola. Išlo o rozsiahlejší stavebný komplex, ktorý bol zložený z viacerých bližšie neurčených budov - universaque edificia domorum in eadem curia existente - ktorý bol pri sporoch členov rodu Ostrolúckych poškodený (MNL DF, 254 176). Žiadne zmienky o rodovom hrade sa nám v stredovekom listinnom materiáli nájst' nepodarilo. Proti tejto možnosti napokon svedčí aj to, že ani najvýznamnejší domáci rod zo Zvolenskej stolice, Radvanskí z Radvane (Ďrková 2005), nemali dostatočné finančné prostriedky na výstavbu hradného areálu.

\section{Zhrnutie a záver}

Na základe doteraz získanej a analyzovanej materiálnej kultúry z hradu Pet’uša je zrejmé, že budovaný bol koncom 13. storočia, existoval počas 14. a 15. storočia a pravdepodobne na prelome 15./16. storočia (prípadne v prvej polovici 16. storočia) ho užívatelia opustili a hrad postupne zanikol.

Kto hrad Pet'uša vybudoval, resp. komu patril, zatial' s istotou nevieme. Ak by hrad tvoril majetkovú súčast' ostrolúckeho panstva, potom by bol jeho budovatel'om niektorý zo šl'achticov z rodu Ostrolúckych. Napovedala by tomu bohatá materiálna kultúra, vel'kost' objektu, mohutné opevnenie a vzdialenost' od hlavnej komunikačnej trasy, ktorá viedla pozdíž druhého brehu Hrona. Žial', tento predpoklad nie je možné zatial' presne overit', nakol'ko nedisponujeme žiadnym historickým prameňom, ktorý by legitimoval hrad ako sídlo rodu. Práve naopak, dostupné informácie skôr túto skutočnost' vylučujú.

Faktom je, že prvá písomná zmienka o obci Ostrá Lúka je z roku 1332, ked' sa spomína v desiatkových súpisoch ako Stoluca (Ďurková 2004, 61). V stredoveku cez ňu viedla obchodná cesta. Písomné pramene zmieňujú v rokoch 1393 (a 1424) pri obci zriadenú král'ovskú mýtnu stanicu pre kupcov a obchodníkov idúcich na trhy do Zvolena, čím vzrástol hospodársky význam tohto územia.

Črtá sa preto d’alšia interpretácia, a to stotožnenie hradu so zmienenou mýtnou stanicou. Toto tvrdenie umocňuje materiálna kultúra s dokladmi dial'kového obchodu, vhodné situovanie hradu nad brodom Hrona a v blízkosti spletí starých furmanských ciest (obr. 5) vedúcich z juhu (od Pliešovskej kotliny) do Zvolena. Mohutné opevnenie by bolo pri takejto funkcii len výhodou. Zároveň je možné, že hrad mal strážnu a kontrolnú funkciu ciest vedúcich v okolí, pričom samotná mýtnica stála pri nich.

Zánik hradu Pet'uša na prelome 15./16. storočia dokladá objavená hmotná kultúra, ktorá neprekračuje prah renesančného umenia. Do záverečnej etapy „využívania“ areálu hradu radíme napr. rozbitú nádobu s vnútornou červenou glazúrou, datovanú na prelom 15./16. storočia, resp. prvej polovice 16. storočia (Beljak Pažinová 2017, 464-465, obr. 12). Zároveň treba podotknút', 
že na hrade boli objavené aj tri fragmenty hlinených praslenov (korálikov?) s priemerom $20 \mathrm{~mm}$, so stopami hnedej glazúry. Tieto nálezy je možné datovat' tiež do druhej polovice 15 . storočia až prvej polovice 16. storočia.

Táto posledná etapa na hrade môže mat' súvis s jeho rabovaním. Pri skúmaní cisterny sa ukázalo, že kamenné segmenty z obloženia valcového plášt’a nie sú až po jej dno na pôvodných pozíciách. Zdá sa, že po zániku hradu bol tento kvalitný stavebný materiál postupne vytažený a odnášaný, čím na mieste vznikol obrovský kráter. Naopak v centrálnej časti hradu (severozápadne od cisterny) sa vytvoril kopec, ktorý vznikol vykopávaním izolačnej vrstvy (čierneho kompaktného ílu) cisterny, aby bolo možné približit' sa ku kamenným segmentom opláštenia. V profile rezu tohto navýšenia bolo možné rozpoznat' viaceré zánikové požiarové vrstvy, vrstvy hutného ílu, sutinový zásyp a dokonca aj jeden kamenný segment.

Horizont finálnej deštrukcie hradu Pet'uša tvoria takmer na všetkých skúmaných miestach do červenočierna prepálené hlinené vrstvy, ktoré poukazujú na minimálne dva ničivé požiare hradu, zaznamenané v profiloch výskumných sond na nádvorí.

Archeologický výskum hradu Pet’uša postupne končí a získaná rozsiahla materiálna kultúra i bohaté poznatky $\mathrm{z}$ terénnej práce budú komplexne spracované a prezentované odbornej i laickej verejnosti formou publikácií, výstav a informačných tabúl'. Odkryté hlboké archeologické sondy a nálezové situácie sa podarilo na jeseň 2017 zasypat' a terén upravit' do pôvodnej podoby, aby návšteva hradu nebola pre záujemcov nebezpečná a nedošlo k žiadnym úrazom.

Systematický vedecký výskum, ktorý bol na pamiatke realizovaný, bol vhodne využitý aj na archeologickú prax študentov archeológie a d’alších záujemcov, ako aj nadšencov, ktorí práve na hrade získali prvé archeologické terénne skúsenosti a návyky, ktoré efektívne využijú aj pri svojej d’alšej činnosti.

Príspevok vznikol v rámci riešenia projektu Vedeckej grantovej agentúry Ministerstva školstva, vedy, výskumu a športu Slovenskej republiky a Slovenskej akadémie vied (VEGA) číslo 1/0208/15 Človek a hory v priebehu času - od pravekých hradísk k stredovekým hradom.

\section{Literatúra}

BELJAK, J. a kol. 2014: Pustý hrad vo Zvolene. Dolný hrad 2009-2014. Zvolen - Nitra.

BELJAK PAŽINOVÁ, N., 2017: Vrcholnostredoveký hrad Pet'uša - Die mittelalterliche Burg Pet'uša und ihre postmediävale Nutzung, AH 42, 453-467.

BLAŽKOVÁ, G., 2013: Vývoj raně novověké kuchyňské a stolní keramiky v Čechách na základě souborů z Pražského hradu - The development of Early Modern ceramic kitchenware and tableware in Bohemia based on assemblages from Prague Castle, PA CIV, 183-230.

BLAŽKOVÁ-DUBSKÁ, G., 2007: House of the armoury scribe at Prague Castle - Dům zbrojního písaře na Pražském hradě, Studies in Post-Medieval Archaeology 2, 9-42.

BORZOVÁ, Z., 2016: Polnohospodárske náradie včasného stredoveku na Slovensku. Nitra.

BŘEZINOVÁ, G.-SAMUEL, M., 2007: „Tak čo, našli ste niečo?“, Svedectvo archeológie o minulosti Mostnej ulice v Nitre. Nitra.

BUDAJ, M., 2005: Nové vyhodnotenie nálezov pražských grošov na Slovensku. In: Česká a slovenská numizmatika po deseti letech (1993-2003) (Šimek, E., ed.), 137-148. Pardubice.

- 2006: Nové nálezy pražských grošov zo Slovenska - Neue Funde von Groschen aus dem 14. bis 15. Jahrhundert in der Slowakei, ZbSNM 100, Archeológia 16, 303-310.

BUZÁS, G.-LÁSZLOVSZKY, J. a kol., 2013: The medieval Royal Palace at Visegrad. Budapest.

ĎURKOVÁ, M., 2004: Ostrolúckovci z Ostrej Lúky (Genealógia rodu do konca stredoveku), Historický zborník 15, č. 2, 13-22.

- 2005: Radvanskovci z Radvane. Najstaršie dejiny rodu, Historický časopis 14, č. 2, 60-67.

HANUliAK, V., 1999: Doklady hmotnej kultúry zo Starého Zvolena (Pustého hradu) od 12. do 17. storočia - Materielle Kultur aus Alt-Zvolen (Pustý hrad - Wüste Burg) im 12.-17. Jahrhundert, AH 24, 352-361.

- 2006: Vojenské pevnosti Jána Jiskru vo Zvolene - Militärische Festung des hussitischen Feldherrn Jan Jiskra in Zvolen, AH 31, 259-268. 
HOLL, I., 1963: Középkori cserépedények a budai várpalotából (XIII.-XV. század), Budapest Régiségei 20, 335-394.

HOŠŠO, J., 1971: Biela stredoveká keramika na Slovensku podl'a doterajšieho stavu bádania, Musaica 22, 61-70.

- 1983: Prehl'ad vývoja stredovekej keramiky na Slovensku - Entwicklungsübersicht der mittelalterlichen Keramik in der Slowakei, AH 8, 215-232.

- 1984: Die Dekoration der Keramik im Hoch- und Spätmittelalter in der Slowakei, Musaica 17, $127-144$.

- 1985: Stredoveké hrnčiarstvo na území Gemera, Novohradu a Hontu, Vlastivedné štúdie Gemera 3, 230-262.

JAVOREK, D., 2017: Vrcholnostredoveká keramika z hradu Pet’uša pri Zvolene. Rkp. diplomovej práce, Univerzita Konštantína Filozofa v Nitre.

KOCSIS, E., 2016: Nyugati import asztali kerámiák a visegrádi vár hódoltság kori leletanyagábol - Imported Western Table Wares from the Ottoman Period Findings of Visegrád Castle. In: „A CSERÉP IGAZAT MOND, HA HELYETTE NEM MI AKARUNK BESZÉLNI“. Regionalitás a középkori és kora újkori kerámiában (Simonyi, E.-Tomka, G., edd.), 269-286. Budapest.

MALINIAK, P., 2009: Človek a krajina Zvolenskej kotliny v stredoveku. Banská Bystrica.

MATĚJKOVÁ, K., 2014: Keramický sortiment turnovských domácností. Možnosti zpracování keramických souborů z městských souvrství - Das Keramiksortiment aus den Turnauer Haushalten: Bearbeitungsmöglichkeiten der aus Stadtschichten stammenden Keramikkollektionen, AH 39, 89-117.

MORDOVIN, M., 2016: Egy kora újkori díszkerámiatípus Szécsényböl - An Early Modern Period decorative potery type from Szécsény. In: „A CSERÉP IGAZAT MOND, HA HELYETTE NEM MI AKARUNK BESZÉLNI“. Regionalitás a középkori és kora újkori kerámiában (Simonyi, E.-Tomka, G., edd.), 319-337. Budapest.

MŪ́LLER, R., 1982: A mezőgazdasági vaseszközök fejlődése Magyarországon a késővaskortól a törökök végéig. Zalaegerszeg.

PAŽINOVÁ, N. a kol., 2013: Stredoveká cestná siet’v okolí zvolenského Pustého hradu. Analýza na základe antropogénnych reliéfnych foriem - Mittelalterliches Straßennetz in der Umgebung von Pustý hrad (Wüste Burg) von Zvolen. Analyse auf der Grundlage von anthropogenen Reliefformen, ŠZ AÚ SAV $54,153-170$.

RAGAČ, R., 1998: Zvolen - obraz stredovekého mesta a jeho mestskej kancelárie. Rkp. diplomovej práce, Univerzita Komenského, Bratislava.

SCAPPI, B., 1622: Opera di Bartolomeo Scappi M. dell'arte del cucinare, con laquale si può ammaestrare qual si voglia cuoco, scalpo, trinciante, o maestro di casa: divisa in sei libri con le figure che fanno di bisogno nella cucina. Venetia.

SEDLÁČKOVÁ, H. et al., 2014: Medieval Glass from Bratislava (ca 1200-1450) in the Context of Contemporanenous Glass Production and Trade Contacts - Středověké sklo z Bratislavy (ca 1200-1450) v kontextu soudobé sklářské produkce a obchodních styků, PA CV, 215-264.

ŠPANIHEL, S., 2014: Medieval and modern ceramic in north-western Slovakia - Stredoveká a novoveká keramika severozápadného Slovenska, ŠZ AÚ SAV 55, 141-179.

ŠVEC, A., 2011: Nové vyhodnotenie nálezu pražských grošov zo Zvolena - New Evaluation of the Find of Prague Groats from Zvolen, Slovenská numizmatika 19, 140-147.

TREUE, W., 1965: Das Hausbuch der Mendelschen Zwölfbrüderstiftung zu Nürnberg. Deutsche Handwerkerbilder des 15. und 16. Jahrhunderts. München.

WHITEHOUSE, D., 2010: Medieval Glass for Popes, Princes, and Peasants. The Corning Museum of Glass. Corning.

\section{Zusammenfassung}

\section{Die Burg Pet'uša - Adelssitz oder Mautstation? Eine Konfrontation von archäologischen und historischen Quellen}

Die Burg Pet'uša (Kataster der Gemeinde Ostrá Lúka) hat die maximalen Maße von $44 \times 24 \mathrm{~m}$ und liegt in Bergspornlage oberhalb vom linken Ufer der Gran in der Nähe der Kreisstadt Zvolen. In sechs Grabungssaisons (2011-2017) ist es dem Lehrstuhl für Archäologie der Universität Konstantin der Philosoph in Nitra gelungen, über eine Gesamtfläche von über $150 \mathrm{~m}^{2}$ einen ausgedehnten Teil des Hofes nebst einer Zisterne und einem, wohl zu einem Gebäude (?) gehörenden, mächtigen Steinfundament, einer Wehrmauer, eines Grabens und den umliegenden Terrassen zu untersuchen (Abb. 1). Gleichzeitig wurde die Datierung der Burg (Ende 13. Jahrhundert - 15./16. 
Jahrhundert) und ihre bauhistorische Entwicklung präzisiert. Die Burg war jedoch bisher noch kein Gegenstand einer archivhistorischen Untersuchung.

Der reiche Fundbestand deutet darauf hin, dass das Objekt annähernd zweihundert Jahre in Funktion war. Vom Hof registrieren wir fast 25000 Scherben, über 6000 Tierknochen und fast 2000 Metallgegenstände (Abb. 3:1, 2). Zu den neuen Funden zählt beispielsweise ein gut erhaltener Prager Silbergroschen (Abb. 4) mit einer Prägung von Johann von Luxemburg (1310-1346).

Die Burg Pet'uša liegt an einem gedachten Schnittpunkt mehrerer Keramikumkreise, wobei der größte Teil (90\%) aus Keramik mit bunteren Tonfarben (braun, rot, rosabraun) besteht; es fand sich auch graue Keramik sowie, den geringsten Anteil bildende, weiße und helltonige rot bemalte Keramik (Abb. 6:1). In dem Keramikkomplex waren mehrere spezielle plastische Bodenmarken enthalten (Abb. 7), eine relative Chronologie der Keramik wurde jedoch hauptsächlich anhand der Profilierung der Gefäßränder bestimmt, die von s-förmig profilierten Mündungen mit meist Hohlkehlen- bzw. Wulstrand (Abb. 8:1-4) über trichterförmig profilierte Mündungen mit Hohlkehlenrand, hochgezogenen, eingezogenen bzw. verschieden profilierten Rändern (Abb. 8:5-7) bis hin zu mehrfach profilierten Mündungen, oftmals mit konkaver Profilierung und hoher Variabilität der Randformen (Abb. 8:8, 9,11-13) einschließlich manschettenförmiger Ränder (Abb. 8:10) reichen. Mit der chronologischen Entwicklung der Keramik sind auch Veränderungen in der Verzierung der Gefäßkörper verbunden (Abb. 9).

Speziell ist ein bordeauxrot glasierter Pokal (Becher), der unterhalb des Randes mit einer kleinen runden, himbeerförmigen Scheibe verziert ist (Abb. 10:1), die einen Beleg für die zwischen der zweiten Hälfte des 14. bis zur Wende des 15./16. Jahrhunderts unterhaltenen Fernhandelskontakte darstellt (Import aus österreichischen Werkstätten). In dem Keramikkomplex kam auch ein offenbar von einem Becher/Pokal stammendes Fragment farblosen Glases vor, das mit Aufschmelzungen langgezogener Glastropfen versehen war (Abb. 10:2) und ebenfalls ins 14. Jahrhundert datiert werden kann.

Die Lage von Burg Pet'uša erlaubt es durchaus logisch anzunehmen, dass es sich bei ihr um eine Wachburg handelte, deren wichtigste Aufgabe es war, die dortigen Land- und Wasserwege wohl in Verbindung mit der Erhebung von Mautgebühren zu kontrollieren. In diesem Falle können wir das Objekt mit der Mautstation (tributum) der Gemeinde Ostrá Lúka identifizieren. In den mittelalterlichen Quellen finden sich gemeinhin nur bescheidene Angaben über sie. Zum ersten Mal urkundlich belegt ist sie im Jahr 1393. Ferner figuriert sie in den herrschaftlichen Bestätigungsurkunden der Zvolener Marktprivilegien aus den Jahren 1412, 1478 und zuletzt in einer Urkunde des ungarischen Jagiellonen-Königs Ludwig II. aus dem Jahr 1519.

Gründe für den Untergang der Burg gibt es offenbar mehrere. Außer der ab den vierziger Jahren des 16. Jahrhunderts aktuellen Bedrohung durch die Türken und einer ernsten Störung der Handelsbeziehungen in der Region war die Lage der Mautstation ein weiteres großes Problem. Aus diesem Blickwinkel gesehen ist eine Urkunde des ungarischen Palatins Lorenz Hédervári aus dem Jahre 1437 vielsagend, in welcher die Untergebenen der in der unmittelbaren Umgebung von Burg Pet’uša liegenden Gemeinden Bacúrov, Breznička, Budča, Gunda und Ostrá Lúka auf dem gesamten Gebiet des Komitats von Mautzahlungen befreit wurden. Mit diesem Privileg entzogen sich fast alle in der Umgebung der Mautstation von Ostrá Luká lebenden Bewohner den Mautzahlungen, weswegen deren Existenz somit an Bedeutung verlor.

Der vorliegende Beitrag entstand im Rahmen des Forschungsprojekts der Wissenschaftlichen Förderagentur des Ministeriums für Schulwesen, Wissenschaft, Forschung und Sport der Slowakischen Republik und der Slowakischen Akademie der Wissenschaften (VEGA) Nr. 1/0208/15 Der Mensch und die Berge im Laufe der Zeit - von urzeitlichen Burgwällen bis zu mittelalterlichen Burgen.

doc. PhDr. Noémi Beljak Pažinová, PhD., Katedra archeológie Filozofickej fakulty Univerzity Konštantína Filozofa v Nitre, Hodžova 1, SK 94901 Nitra, Slovenská republika,nbpazinova@ukf.sk

PhDr. Radoslav Ragač, PhD., Sekcia kultúrneho dedičstva Ministerstva kultúry Slovenskej republiky, Námestie SNP 33, SK 81331 Bratislava, Slovenská republika, radoslav.ragac@culture.gov.sk 
